\title{
Assessment and Mapping of Irrigation Water Quality Index of Bapatla Mandal, Guntur District, Andhra Pradesh, India
}

\author{
B. Devojee*, G. Nagababu, M. Manoj Kumar, Y. Nandini and H.V. Hemakumar \\ College of Agricultural Engineering, Bapatla, ANGRAU, Andhra Pradesh, India \\ *Corresponding author
}

\begin{tabular}{|l|}
\hline Ke y w or d s \\
Irrigation, Water \\
quality index, \\
Analyze
\end{tabular}

\section{A B S T R A C T}

An investigation is carried out to analyze the irrigation water quality in 26 villages in Bapatlamandal for their quality parameters and comprehensively arriving at a single water quality index. The irrigation water samples were collected manually from the bore wells which are approximately equally distributed all over 26 villages of Bapatla region. The samples were analyzed using standard procedures in the laboratory (APHA, 1985). The parameters analyzed during the analysis are $\mathrm{pH}, \mathrm{EC}$, Chlorides, Calcium, Magnesium (Mg), Total Dissolved Solids (TDS), Total Hardness (TH). From the investigation, it is clearly evident that the irrigation water of the area needs some degree of treatment before consumption. Based on the investigations carried out, it is observed that Asodivaripalem, West Bapatla, Cheruvujamulapalem, Murukondapadu, Muthayapalem, Maruproluvaripalem and Vodarevu villages contain water quality very poor for irrigation purpose due to over salt accumulation. Necessary measures are to be taken to gain safe irrigation and drinking water to the people living in the villages. Total hardness was found to be very high in Murukondapadu, and Muthayapalem villages. Very high concentrations of chloride, calcium and magnesium were found in West Bapatla, Cheruvujamulapalem, Murukondapadu and Muthayapalem villages. The water quality is good in Jillelamudi, Mulapalem, Etheru, Bhartipudi, Tsundurupalli, Gopapuram, Appikatla, East Bapatla, Kondubotlavaripalem and Poondla villages based on Water Quality Index. The water quality was found moderately well in Vedullapalli, Bethapudi, Pinniboinavaripalem, Gudipudi, Stuvartpuram, Kankatapalem, Marripudi and Narasayapalem villages.

\section{Introduction}

World's global water resources accounts for $97.5 \%$ out of which $2.5 \%$ fresh water resources in which India fresh water resources accounts for 7 to $17 \%$ which is inclusive of both surface $64 \%$ and ground water resources $36 \%$ out of which domestic purpose $5 \%$, industries $6 \%$ and agricultural $89 \%$. In the increased globalization scenario, a paradigm shift is being foreseen in increasing the industrialization major shift of agricultural land put to non- agricultural use perhaps the reduction in water allocation for crop production sector possess a great threat for agricultural sustainability. Besides even for drinking water for the alarming rate of increased population, it is very critical and important to treat the waste water and re use for some non-important activities. Hence there 
is a great focus in assessing the water quality at point source.

Ground water is a precious natural gift and an important renewable resource having several inherent advantages over surface water. It is a good source of fresh water available on the earth. The demand for water has increased over the years and this has led to water scarcity in many parts of the world. The situation is aggravated by the problem of water pollution or contamination. India is heading towards a fresh water crisis mainly due to improper management of water resources and environmental degradation. This leads to lack of access to safe potable water supply to millions of people. It becomes imperative to regularly monitor the quality of ground water and to device ways and means to protect it. Water Quality Index is one of the most effective tools to communicate information on overall quality status of water to the concerned user community and policy makers (Chopra and Anwar, 1999). Thus, it becomes an important parameter for the assessment and management of ground water.

Contamination often goes undetected for many years. One of the most disturbing aspects of the problem is that groundwater and soil pollution is essentially permanent. Water recycles too slowly in the underground to flush out or dilute toxic chemicals. Water that enters an aquifer remains there for several years, compared to only 16 days for surface waters. Groundwater in certain parts, especially in areas on either side of major bodies, is greatly polluted due to disposal of industrial effluents, sewage, domestic solid wastes and other pollutants.

In case of agricultural lands with underground saline water to a widely varying extent, with in a Panchayath/Municipality level, the underground water quality, soil extract salinity should be documented for better crop planning. However, uncontrolled extraction without commensurate recharge and leaching of pollutants from pesticides and fertilizers into the aquifers has resulted in pollution of groundwater supplies. In addition to leachate from agriculture, ground water is threatened with pollution from various sources viz., domestic wastes, industrial wastes, agricultural wastes, run off from urban areas and soluble effluents.

\section{Study area}

Bapatla Mandal occupies a geographic extent of about $30 \mathrm{~km}^{2}$ and the decennial average rainfall is about $1031.1 \mathrm{~mm}$ of which $621 \mathrm{~mm}$ is received during the south-west monsoon. $319.5 \mathrm{~mm}$ in the north-east monsoon and 90.4 $\mathrm{mm}$ during the rest of the year. This mandal lies between $16^{0} 56^{\prime} 87.586^{\prime}$ " to $15^{\circ} 54^{\prime}$ north latitude and $78^{\circ} 31^{\prime} 1.298^{\prime \prime}$ to $80^{\circ} 30^{\prime}$ east longitude.. It is located $51 \mathrm{Km}$ towards South from District headquarters Guntur. It is a Mandal headquarter.

The average elevation is $5 \mathrm{~m}$ above the sea level. It has a population of above 70777 according to census 2011. Among them Males are 34385 and Females are 36392 living in Houses. This Place is in the border of the Guntur District and Prakasam District. Prakasam District Chirala is west towards this place. It is near to Bay of Bengal. There is a chance of humidity in the weather.

It is bounded on the south by Guntur Districts. On the north by Ponnur and Repalle, on the east by Bay of Bengal and on the west by Parchuru and Prathipadu. Many areas in this district depend on ground water for drinking and other purposes. The base map representing the boundaries of 25 villages are collected from mandal office, bapatla. Map of the study area is shown in the following Figure. 


\section{Materials and Methods}

\section{Sample collection}

The irrigation water quality in villages of BapatlaMandal was analyzed by collecting the 3 samples of water from each village. Samples are collected from cultivated areas.

These samples are analyzed at soil science laboratory agricultural college Bapatla for $\mathrm{pH}$, EC, TDS, TH, Ca, Mg and chlorides. The lists of villages taken into consideration for this present investigation are enlisted in Table1.

\section{Estimation of water quality index}

Water Quality Index (WQI) is a very useful and efficient method for assessing the quality of water. Water Quality Index is very useful tool for communicating the information on overall quality of water.

To determine the suitability of the groundwater for drinking purpose, WQI is computed by adopting the following formula. Table 2 provides the information about water quality parameter, their BIS standards and weight ages and table 3 provides the information of water quality index categories.

\section{Calculation of water quality index}

$\mathrm{WQI}=\Sigma\left(\mathrm{q}_{\mathrm{i}} \mathrm{w}_{\mathrm{i}}\right) / \Sigma \mathrm{w}_{\mathrm{i}}$

Where,

$\mathrm{q}_{\mathrm{i}}($ water quality rating $)=1000^{\left[\frac{\mathrm{Va}-\mathrm{Vi}}{\mathrm{V}-\mathrm{Vi}}\right]}$

$\mathrm{v}_{\mathrm{a}}=$ actual value present in the water sample.

$\mathrm{v}_{\mathrm{i}}=$ ideal value ( 0 for all parameters except $\mathrm{pH}$ and DO)

$\mathrm{w}_{\mathrm{i}}($ unit weight $)=\mathrm{k} / \mathrm{S}_{\mathrm{n}}$
$\mathrm{K}($ constant $)=\frac{1}{((1 / V s 1)+(1 / V s 2)++\ldots(1 / V s n))}$

$\mathrm{S}_{\mathrm{n}}=$ standard value

\section{Results and Discussion}

\section{Collection of water samples from the study area}

As discussed in the above irrigation water samples one from each village were collected and analyzed in the Soil Science Laboratory of Agricultural College, Bapatla. The samples were collected directly from the source of irrigation i.e. either from bore wells or from outlets of canals into the agricultural fields.

\section{Analysis of water samples for its quality in the study area}

The quality of irrigation water varies from place to place; even at the same location, from season to season. It also depends upon both the surface and subsurface characteristics.

Presence of landfills, open dump, usage of fertilizers, disposal of industrial wastes etc. Change the quality of irrigation water. As part of the investigations, the quality parameters like Chlorides, Calcium, Magnesium, TH, pH, EC and TDS were analysed. The results are reported in the following sections.

\section{Chlorides}

The Chlorides concentration was found to be less than $250 \mathrm{mg} / \mathrm{lt}$ for the villages namely, Adivi, Vedullapalli, Asodivaripalem, Bharthipudi, Gopapuram, Bethapudi etc. The villages namely, West Bapatla, Cheruvjamullapalem, Murukondapadu showed concentration levels ranging from 250-500 mg/lt. A very high concentration level of more than $500 \mathrm{mg} / \mathrm{lt}$ was found in Muthayapalem and Vodarevu villages. 
Fig.1 Location map of the study area

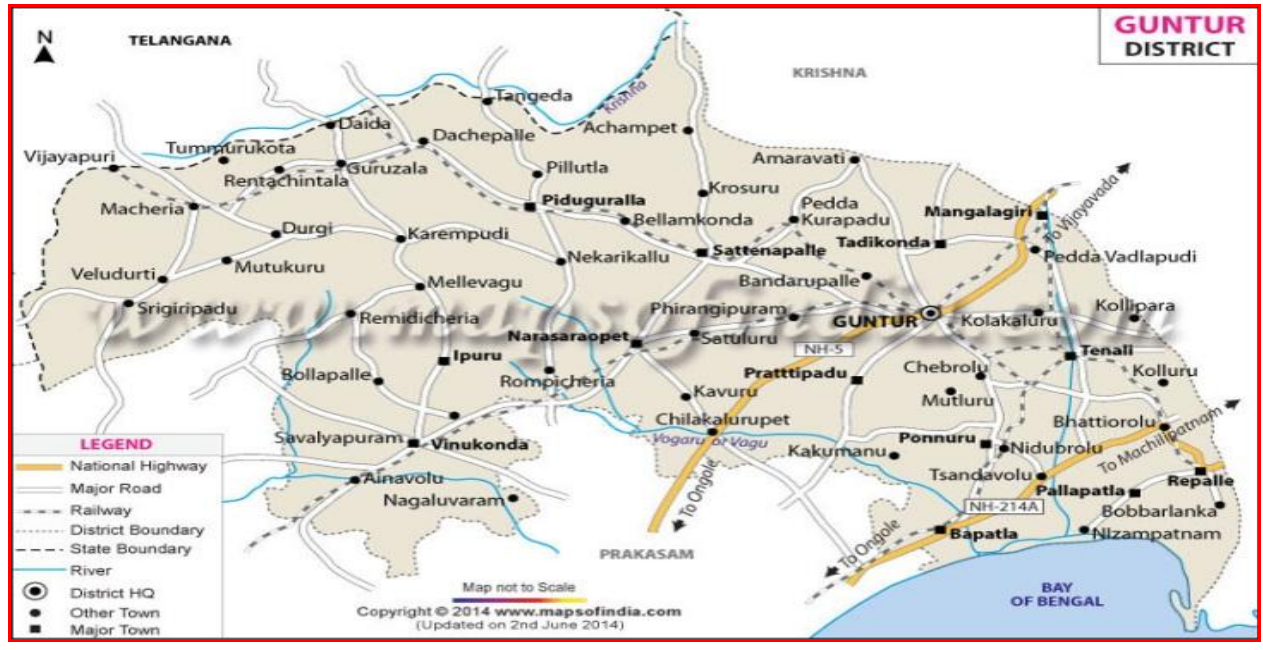

Table.1 List of villages considered for the present study in Bapatla Mandal

\begin{tabular}{|c|l|c|l|}
\hline SI. No & \multicolumn{1}{|c|}{ Village } & SI. No & \multicolumn{1}{|c|}{ Village } \\
\hline $\mathbf{1}$ & Adivi & 14 & Poondla \\
\hline $\mathbf{2}$ & West Bapatla & 15 & Jillellamudi \\
\hline $\mathbf{3}$ & Vedullapalli & 16 & Mulapalem \\
\hline $\mathbf{4}$ & Asodivaripalem & 17 & Stuvartupuram \\
\hline $\mathbf{5}$ & Bharthipudi & 18 & Murukondapadu \\
\hline $\mathbf{6}$ & Gopapuram & 19 & Kankatapalem \\
\hline $\mathbf{7}$ & Bethapudi & 20 & Muthayapalem \\
\hline $\mathbf{8}$ & Appikatla & 21 & Maruprolluvaripalem \\
\hline $\mathbf{9}$ & Cheruvjamullapalem & 22 & Marripudi \\
\hline $\mathbf{1 0}$ & East Bapatla & 23 & Etheru \\
\hline $\mathbf{1 1}$ & Pinniboinavaripalem & 24 & Tsundurupalli \\
\hline $\mathbf{1 2}$ & Gudipudi & 25 & Narasayapalem \\
\hline $\mathbf{1 3}$ & Kondubotlavaripalem & 26 & Vadarevu \\
\hline
\end{tabular}

Table.2 Water quality parameter, their BIS standards and weightages

\begin{tabular}{|l|l|l|l|}
\hline SI. No. & \multicolumn{1}{|c|}{ Parameter } & \multicolumn{1}{c|}{ Standard (Sn and Si) } & Weightage (Wi) \\
\hline $\mathbf{1}$ & $\mathrm{pH}$ & 8.5 & 0.1363529 \\
\hline 2 & Calcium $(\mathrm{mg} / \mathrm{l})$ & 75 & 0.0154533 \\
\hline 3 & Chlorides $(\mathrm{mg} / \mathrm{l})$ & 250 & 0.0046360 \\
\hline 4 & Flourides $(\mathrm{mg} / \mathrm{l})$ & 1.5 & 0.7726666 \\
\hline 5 & Total Hardness $(\mathrm{mg} / \mathrm{l})$ & 300 & 0.0038633 \\
\hline 6 & Mg (mg/l) & 30 & 0.0386333 \\
\hline 7 & Nitrates $(\mathrm{mg} / \mathrm{l})$ & 45 & 0.0257555 \\
\hline $\mathbf{8}$ & TDS $(\mathrm{mg} / \mathrm{l})$ & 500 & 0.00231800 \\
\hline
\end{tabular}


Table.3 Water quality index categories (source: Rao et al., 2013)

\begin{tabular}{|l|l|l|}
$\begin{array}{l}\text { SI. } \\
\text { No. }\end{array}$ & $\begin{array}{l}\text { Water Quality Index } \\
\text { (WQI) }\end{array}$ & Description \\
\hline 1 & $<50$ & Excellent \\
\hline 2 & $50-100$ & Good \\
\hline 3 & $100-200$ & Moderately good \\
\hline 4 & $200-300$ & Poor \\
\hline 5 & $>300$ & Very poor \\
\hline
\end{tabular}

Table.4 Summary of quality parameters of irrigation water samples of Bapatla Mandal

\begin{tabular}{|c|c|c|c|c|c|c|c|c|}
\hline $\begin{array}{l}\text { SI. } \\
\text { No. }\end{array}$ & Village & pH & $\begin{array}{c}\mathrm{Ca} \\
(\mathrm{mg} / \mathrm{l})\end{array}$ & $\underset{(\mathrm{mg} / \mathrm{l})}{\mathrm{Cl}}$ & $\begin{array}{c}\mathrm{TH} \\
(\mathrm{mg} / \mathrm{l})\end{array}$ & $\begin{array}{c}\mathrm{Mg} \\
(\mathrm{mg} / \mathrm{l})\end{array}$ & $\begin{array}{l}\text { TDS } \\
\mathrm{mg} / \mathrm{l}\end{array}$ & $\begin{array}{c}\mathrm{EC} \\
(\mathrm{mg} / \mathrm{l})\end{array}$ \\
\hline 1 & Adivi & 6.53 & 76 & 49.7 & 112 & 36 & 400 & 480 \\
\hline 2 & West Bapatla & 6.56 & 114 & 276.9 & 240 & 126 & 0 & 1773 \\
\hline 3 & Vedullapalli & 6.03 & 100 & 113.6 & 140 & 40 & 0 & 928 \\
\hline 4 & Asodivaripalem & 6.30 & 62 & 170.4 & 128 & 66 & 400 & 1523 \\
\hline 5 & Bharthipudi & 6.91 & 34 & 42.6 & 52 & 18 & 0 & 326 \\
\hline 6 & Gopapuram & 7.43 & 40 & 49.7 & 64 & 24 & 0 & 422 \\
\hline 7 & Bethapudi & 6.07 & 116 & 127.8 & 152 & 36 & 0 & 973 \\
\hline 8 & Appikatla & 6.42 & 44 & 49.7 & 124 & 80 & 200 & 403 \\
\hline 9 & Cheruvjamullapalem & 6.61 & 134 & 291.1 & 200 & 66 & 200 & 1990 \\
\hline 10 & East Bapatla & 6.20 & 38 & 56.8 & 76 & 38 & 200 & 486 \\
\hline 11 & Pinniboinavari & 6.36 & 74 & 163.3 & 124 & 50 & 0 & 966 \\
\hline 12 & Gudipudi & 6.18 & 64 & 177.5 & 136 & 72 & 0 & 986 \\
\hline 13 & Kondubotlav & 6.25 & 90 & 49.7 & 124 & 34 & 0 & 544 \\
\hline 14 & Poondla & 6.26 & 38 & 56.8 & 96 & 58 & 0 & 390 \\
\hline 15 & Jillellamudi & 6.28 & 50 & 49.7 & 116 & 66 & 200 & 332 \\
\hline 16 & Mulapalem & 6.14 & 18 & 56.8 & 52 & 34 & 0 & 346 \\
\hline 17 & Stuvartupuram & 6.02 & 94 & 134.9 & 144 & 50 & 0 & 780 \\
\hline 18 & Murukondapadu & 6.25 & 60 & 291.9 & 172 & 112 & 400 & 1587 \\
\hline 19 & Kankatapalem & 6.07 & 64 & 156.2 & 128 & 64 & 200 & 915 \\
\hline 20 & Muthayapalem & 6.65 & 84 & 553.8 & 232 & 148 & 200 & 2982 \\
\hline 21 & Maruprolluvaripalem & 6.64 & 144 & 163.3 & 212 & 68 & 200 & 1158 \\
\hline 22 & Marripudi & 6.32 & 50 & 56.8 & 160 & 110 & 0 & 410 \\
\hline 23 & Etheru & 6.33 & 44 & 42.6 & 100 & 56 & 0 & 339 \\
\hline 24 & Tsundurupalli & 6.30 & 54 & 71 & 108 & 54 & 0 & 454 \\
\hline 25 & Narasayapalem & 6.04 & 56 & 191.7 & 116 & 60 & 400 & 928 \\
\hline 26 & Vodarevu & 6.50 & 85 & 553.9 & 233 & 149 & 203 & 2980 \\
\hline
\end{tabular}


Table.5 Averages of various parameters of all villages along with WQI

\begin{tabular}{|l|l|l|l|l|l|}
\hline SI. No. & \multicolumn{1}{|c|}{ village } & WQI & SI. No. & \multicolumn{1}{c|}{ village } & \multicolumn{1}{|c|}{ WQI } \\
\hline $\mathbf{1}$ & Adivi & 129.57 & 14 & Poondla & 108.83 \\
\hline $\mathbf{2}$ & West Bapatla & 547.91 & 15 & Jillellamudi & 98.53 \\
\hline $\mathbf{3}$ & Vedullapalli & 271.54 & 16 & Mulapalem & 84.76 \\
\hline $\mathbf{4}$ & Asodivaripalem & 465.13 & 17 & Stuvartupuram & 224.37 \\
\hline $\mathbf{5}$ & Bharthipudi & 82.25 & 18 & Murukondapadu & 488.55 \\
\hline $\mathbf{6}$ & Gopapuram & 116.98 & 19 & Kankatapalem & 269.23 \\
\hline $\mathbf{7}$ & Bethapudi & 286.28 & 20 & Muthayapalem & 936.54 \\
\hline $\mathbf{8}$ & Appikatla & 127.06 & 21 & Maruprolluvaripalem & 346.58 \\
\hline $\mathbf{9}$ & Cheruvjamullapalem & 615.28 & 22 & Marripudi & 153.85 \\
\hline $\mathbf{1 0}$ & East Bapatla & 129.89 & 23 & Etheru & 94.18 \\
\hline $\mathbf{1 1}$ & Pinniboinavaripalem & 284.46 & 24 & Tsundurupalli & 125.56 \\
\hline $\mathbf{1 2}$ & Gudipudi & 293.14 & 25 & Narasayapalem & 272.78 \\
\hline $\mathbf{1 3}$ & Kondubotlavaripalem & 148.30 & 26 & Vodarevu & 936.19 \\
\hline
\end{tabular}

\section{Calcium}

The high concentration of calcium traces in the range $75-200 \mathrm{mg} / \mathrm{lt}$ are found in the villages; Adivi, West Bapatla, Vedullapalli, Bethapudi,

Kondubotlavaripalem, Muthayapalem, Vodarevu. Cheruvjammulapalem, Stuvartupuram, Maruprolluvaripalem,

\section{Total Hardness}

The villages with less than $200 \mathrm{mg} / \mathrm{l}$ concentration of irrigation water are Adivi, Vedullapalli, Asodivaripalem, Bharthipudi, East Bapatla, Poondla, Mulapalem etc. The average concentrations lying between 200$300 \mathrm{mg} / \mathrm{l}$ of total hardness was found in West Bapatla, Cheruvjamullapalem, Muthayapalem and Vodarevu. Total hardness of above 600 $\mathrm{mg} / \mathrm{l}$ concentration level requires softening to make water potable for drinking.

\section{Magnesium}

The concentration of magnesium was found to be within the permissible limits in the villages; Bharthipudi, Gopapuram,
Kondubotlavaripalem, Mulapalem, Adivi etc. The magnesium concentration was in between $30-100 \mathrm{mg} / \mathrm{l}$ in the villages Vedullapalli, Asodivaripalem, Appikatla, Pinniboinavaripalem, Poondla, Jillellamudi, Etheru, Narasayapalem etc. The villages; West Bapatla, Murukondapadu, Marripadu, Vodarevu showed very high concentrations of magnesium.

\section{pH}

The irrigation water samples of most of the villages showed $\mathrm{pH}$ less than 6.5 which may not cause tuberculation of water in the pipes and slightly acidic in nature. There is no sample with more than $8.5 \mathrm{pH}$ Which cause incrustation in water supply systems. The villages; Adivi, West Bapatla, Bharthipudi, and Gopapuram etc. showed within the range of $6.5-7.5 \mathrm{pH}$ (neutral).

\section{Electrical conductivity (EC)}

Conductivity is a measure of current carrying capacity. Thus, as concentration of dissolved salts increases, conductivity increases. The conductivity is observed in the range of 300 
to $1000 \mathrm{mg} / \mathrm{l}$ in the water samples of Adivi, Appikatla, East Bapatla, Poondla, Stuvartupuram, Kankatapalem, and Maruprolluvaripalem. High concentration of EC is observed in the water samples of Narasayapalem, Murukondapadu, Jamullapalem, Asodivaripalem villages.

\section{Total dissolved solids (TDS)}

TDS values of water samples of all villages ranged between 420 to $709 \mathrm{mg} / \mathrm{l}$. As per standards, this water is suitable for irrigation purposes. Most of the villages showed TDS in permissible limits useful for potable purpose.

\section{Estimation of water quality index}

As per the methodology reported in the above, weighted parameter i.e. Water Quality Index (WQI) was calculated for each village and is presented in the below. The variations of WQI of the irrigation water ranged between 82.25 to 936.54 in different villages of Bapatla Municipality.

It is observed that Asodivaripalem, West Bapatla, Cheruvujamulapalem, Murukondapadu, Muthayapalem, Maruproluvaripalemand Vodarevu villages contain water quality very poor for irrigation purpose due to over salt accumulation. Necessary measures are to be taken to gain safe irrigation and drinking water to the people living in the villages. Total hardness was found to be very high in Murukondapadu, and Muthayapalem villages.
Very high concentrations of chloride, calcium and magnesium were found in West Bapatla, Cheruvujamulapalem, Murukondapadu and Muthayapalem villages.

The water quality is good in Jillelamudi, Mulapalem, Etheru, Bhartipudi, Tsundurupalli, Gopapuram, Appikatla, East Bapatla, Kondubotlavaripalem and Poondla villages based on Water Quality Index. The water quality was found moderately good in Vedullapalli, Bethapudi, Pinniboinavaripalem, Gudipudi, Stuvartpuram, Kankatapalem, Marripudi, and Narasayapalem villages.

\section{References}

APHA 1985. Standard methods for the examination of water and wastewater American Public Health Association, New York, U.S.A.

BIS 10500-1991-- Bureau of Indian standards for drinking water.

Chopra. S.L, and Anwar, J.S., 1999. Analytical Agricultural Chemistry, Kalyani pub., p 292.

Manivasakam, N. Physico Chemical Examinationm of Water. Sewage and Industrial Effluents, PragatiPrakasham, pp 234.

Rama Krishnaiah C.R., 2008/ Assessment of Water Quality Index for the Groundwater in Tumkur Taluk, Karnataka State, India

\section{How to cite this article:}

Devojee, B., G. Nagababu, M. Manoj Kumar, Y. Nandini and Hemakumar, H.V. 2018. Assessment and Mapping of Irrigation Water Quality Index of Bapatla Mandal, Guntur District, Andhra Pradesh, India. Int.J.Curr.Microbiol.App.Sci. 7(01): 1914-1920. doi: https://doi.org/10.20546/ijcmas.2018.701.230 